підготов. й вдоскон. журналістів (Париж), Ін-т мас. інформації (Київ). Київ : [б. в.], 1999. - 96 с.

4. Гладун О. Візуалізація інформації: інфографіка.

5. Симакова С. И. Клиповизация мышления у молодежи как следствие развития визуальных коммуникаций в СМИ. - URL : https:/cyber leninka.ru/article/v/klipovizatsiya-myshleniya-u-molodezhikak-sledstvierazvitiya-vizualnyh-kommunikatsiy-v-smi

6. Цуканова Г. О. Інфографіка як ефективний візуальний складник рекламного повідомлення. Наукові записки Інституту журналістики. Том 50. 2013. Січень-березень.

7. Швед О. Інфографіка як засіб візуальної комунікації в сучасній журналістиці. URL : http://nbuv.gov.ua/UJRN/gotvnz_2014_30_29

8. Шевченко В.Е. Форми візуалізації в сучасному журналі : монографія. Київ нац. ун-т ім. Тараса Шевченка. Київ : Видавець ПАЛИВОДА A.B., 2013. 340 c.

DOI: http://doi.org/10.31617/k.knute.2019-03-19.19

\title{
ЗОВНІШНЯ РЕКЛАМА В ЧЕРКАСАХ: ОСНОВНІ ВИДИ
}

\author{
Баранник В. О. \\ студент 2-го курсу \\ спеціальності «Реклама та PR у медіагалузі» \\ Надточій О. Л. \\ к. філол. Н., доцент \\ кафедра журналістики, реклами та PR-технологій \\ HНI української філології та соціальних комунікацій \\ Черкаський національний університет ім. Б. Хмельницького, \\ Украӥна
}

Ключові слова: реклама, зовнішня реклама, види зовнішньої реклами.

Keywords: advertising, outdoor advertising, types of outdoor advertising.

Успіх рекламної кампанії залежить насамперед від правильно обраного виду рекламного звернення. Різні види реклами, які розподіляють залежно від засобів передання інформації, мають специфічні характеристики, що визначають переваги та недоліки їхнього застосування в певних ситуаціях. Зовнішня реклама має властивості, що визначають іiі компліментарність рекламним цілям великої частки підприємств, а саме: іiі відносно низьку вартість, локальний характер 
розміщення, відсутність вибірковості аудиторії та високу частоту контактів [2].

Визначень терміну «зовнішня реклама» існує досить багато. Так, у Законі України «Про рекламу» зазначено, що зовнішня реклама реклама, яку розміщують на спеціальних тимчасових і стаціонарних конструкціях-рекламоносіях, розташованих на відкритій місцевості, а також на зовнішніх поверхнях будинків, споруд, на елементах вуличного обладнання, над проїжджою частиною вулиць і доріг [1]. Відповідно до визначення дослідника Є. В. Ромата, «зовнішня реклама медіаканал, що доносить рекламні звернення до одержувача за допомогою надрукованих плакатів, мальованих щитів або світлових табло, встановлюваних у місцях найбільш жвавого вуличного руху, а також уздовж шосейних доріг та залізниць» [2].

Український термін «зовнішня реклама» $\epsilon$ перекладом 3 англійської слова outdoor, яке дослівно означає «поза дверима». У країнах 3 давніми традиціями ведення рекламного бізнесу, таких як США, Великобританія та Канада, користуються ширшим поняттям - «реклама поза домівкою» (out-of-home), що включає не тільки outdoor-pекламу, а також рекламу в транспортних засобах і на них, у метро та аеропортах, стадіонах та ін. [3]. Класифікація реклами «поза домівкою», подана Outdoor advertising association of America, включає такі види реклами: білборди, вуличні меблі, транспорт (всередині та зовні), альтернативні (авіаційна, всередині та зовні портів, стадіонів, арен та у кінотеатрах) [3]. Традиційною класифікацією зовнішньої реклами вважаємо іiї поділ на такі види: дорожні розтяжки, сітілайти, білборди, брандмауери, рухомі рядки, троли, афіші та реклама в і на транспорті.

Відповідно, за нашими спостереженнями, найбільш поширеними в місті Черкаси є такі види зовнішньої реклами, як: білборд, призматрон, лайтбокс, штендер та реклама на транспорті. Розглянемо їх детальніше.

Лідером серед зовнішньої реклами, за нашими спостереженнями, $\epsilon$ білблорд. Завдяки розмірам, ця реклама привертає до себе увагу перехожих, пасажирів маршрутних транспортних засобів та водіїв. Це забезпечує велику кількість контактів аудиторії за своєї відносно низької собівартості. Таку рекламу переважно встановлюють на людних перехрестях, де іiі можна добре розгледіти як з дороги, так і з тротуару. На таких конструкціях розміщують свою рекламу магазини техніки Comfy тa Eldorado, а також ТРЦ «Lubava» та ТРЦ «Дніпро Плаза», що зазвичай повідомляють про знижки чи новинки. Поблизу кожного зі своїх магазинів білборди також використовує мережа супермаркетів «Делікат».

Не менш поширеним видом зовнішньої реклами в Черкасах, за нашими спостереженнями, є призматрон. Конструкція за розмірами 
співвідносна із білбордом, але складається 3 рухомих тригранних елементів, на кожному 3 яких розміщено окреме зображення. Такі рекламні конструкції розташовують у локаціях, схожих із локаціями білбордів. Цей вид реклами однозначно привертає до себе значно більше уваги, завдяки руху рекламних елементів призматрону. Цим видом зовнішньої реклами активно користуються магазини хутряного одягу «ANT» та «Allu-R».

Ще одним видом зовнішньої реклами, часто використовуваної у місті, є лайтбокси. Конструкція має вигляд «коробки» із підсвіткою зсередини. Найчастіше їх використовують біля офісів, магазинів рекламодавців. Цей вид зовнішньої реклами використовують магазини «Казбет», «Велика кишеня» та «Freeride».

Популярним в Черкасах також, за нашими спостереженнями, $\epsilon$ такий носій зовнішньої реклами, як штендер. Це невеликі рекламні конструкції, які розміщують безпосередньо біля предмету рекламування перукарні, кафе, барів. На таких носіях часто розміщують актуальну інформацію - прейскурант або відомості про знижки. Штендери використовують кафе «Caffeine», «Fika» та «Чашка».

Окремо варто виділити рекламу на транспорті. В місті, за нашими сппостереженнями, кожні 7 iз 10 маршруток $€$ «пересувними рекламоносіями». Таку рекламну площу використовують, наприклад, хімчистка «DONINI» та інтернет ресурс «Avto.ria»

Для того, щоб отримати дані щодо популярності тих чи тих видів зовнішньої реклами, проаналізовано 100 рекламних звернень у період із 1.02.2019 по 15.02.2019

Результати дослідження вважаємо за необхідне представити на рис. 1.

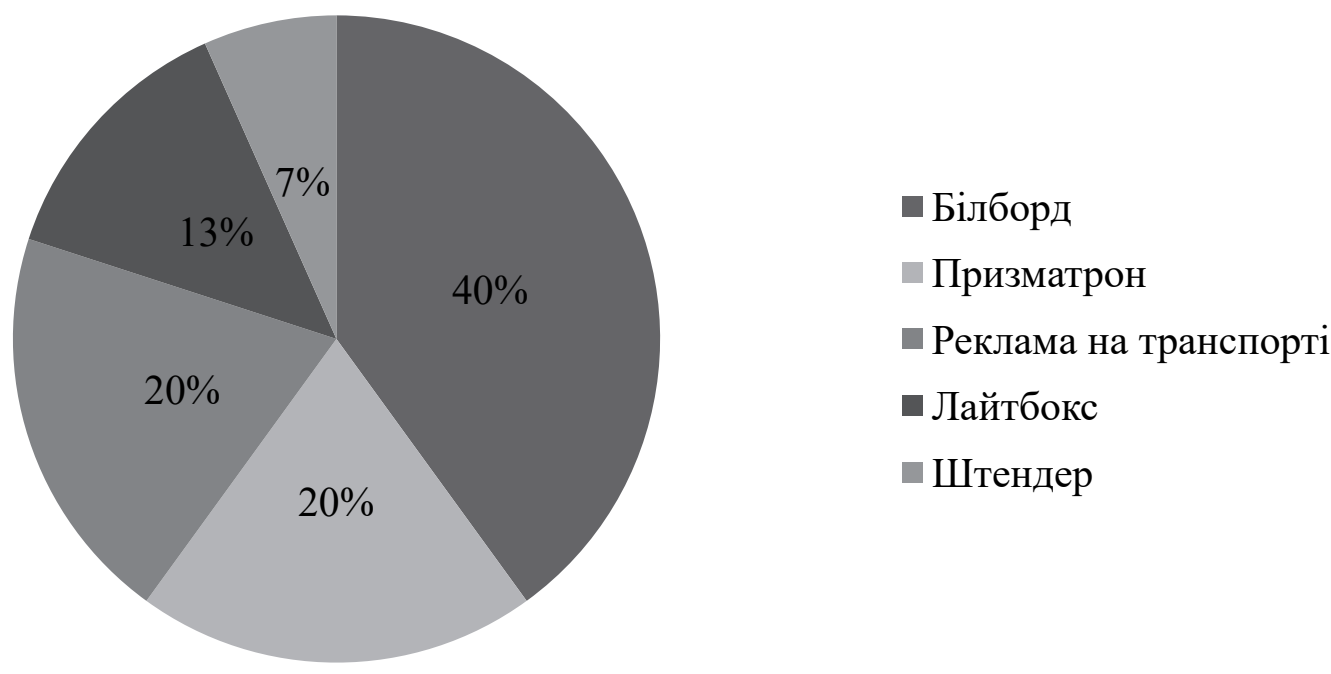

Рис. 1. Види реклами, \% 
Зовнішня реклама - ефективний спосіб просування товару чи фірми. Її активно використовують у масштабних рекламних кампаніях різноманітних товарів, брендів та послуг.

Розглянута в статті проблема не претендує на вичерпність, тема є перспективною для подальших наукових досліджень.

\title{
Список використаних джерел
}

1. Закон України «Про рекламу» [Електронний ресурс]. - Режим доступу : https://zakon2.rada.gov.ua/laws/show/270/96-\%D0\%B2\% D1\%80.

2. Мельникович О. М. Зовнішня реклама : монографія / О. М. Мельникович, А. С. Крепак. - Київ : Київ. нац. торг.-екон. ун-т, 2017. - 220 с.

3. OAAA Committees and Counsils [Електронний ресурс] / Outdoor advertising association of America. - Режим доступу : http://www.oaaa.org/about/commettees.aspx

DOI: http://doi.org/10.31617/k.knute.2019-03-19.20

\section{СОЦАЛЬНІ КОМУНІКАЦІї В УМОВАХ ЦИФРОВОЇ ЕКОНОМІКИ}

\author{
Баюра Д.О. \\ д.е.н., професор, \\ кафедра економіки підприємства \\ Київський національний університет ім. Тараса Шевченка, \\ Украӥна
}

Ключові слова: сочіальний діалог, сочіальні мережі, стейкхолдери, великі дані, корпоративна сочіальна відповідальність, корпоративна репутація, корпоративні ризики.

Keywords: social dialogue, social networking, stakeholder, large data, corporate social responsibility, corporate reputation, corporate risk.

Соціальний діалог i розвинуті комунікації із усіма заінтересованими особами (стейкхолдерами) є основою формування високого рівня корпоративної культури та професійної етики в організаціях та підприємствах корпоративного типу. Виходячи iз імплементації ключових положень теорій груп та заінтересованих осіб в 